Original Research Paper

\title{
The Potency of Kirinyuh (Chromolaena odorata L.) and Kemangi leaf (Ocimum basilicum) as Biopesticide against Schizophyllum commune Fries
}

\author{
Farah Diba $^{1 *}$, Ulvatur Rochmawati Nauli ${ }^{1}$, Wiwik Winarsih ${ }^{1}$, H A Oramahi ${ }^{1}$ \\ ${ }^{1}$ Fakultas Kehutanan, Universitas Tanjungpura, Pontianak, Indonesia
}

\author{
Article History \\ Received : October 12 $2^{\text {th }}, 2021$ \\ Revised : December 28 ${ }^{\text {th }}, 2021$ \\ Accepted : January 20 ${ }^{\text {th }}, 2022$ \\ Published : January 29 2022 \\ *Corresponding Author: \\ Farah Diba, \\ Fakultas Kehutanan Universitas \\ Tanjungpura, Pontianak, \\ Indonesia; \\ Email: \\ farahdiba@fahutan.untan.ac.id
}

\begin{abstract}
Schizophyllum commune Fries is a wood rot fungus that attacks living trees and wood products which causes high economic losses. The research objective was to evaluate the extracts of kirinyuh (Chromolaena odorata $\mathrm{L}$ ) and kemangi (Ocimum basilicum $\mathrm{L}$ ) as a biopesticide to control Schizophyllum commune Fries. The solvents used for extracting the leaves of Kirinyuh and kemangi were $96 \%$ ethanol solvent in a ratio of 1: 3 $(\mathrm{w} / \mathrm{v})$. The extracts then formed into $2 \%, 4 \%, 6 \%, 8 \%$, and $10 \%$ concentration and mixed into PDA medium. The media was poured into a petri dish and then kept in incubator room. Then the isolates of Schizophyllum commune Fries fungus, seven days old with a five mm diameter, were put in the medium center. The parameter test was the value inhibition the fungal growth, comparing control treatment and the given concentration treatment. The results of research showed that kirinyuh leaf extract at a concentration of $2 \%$ has strong antifungal values with growth inhibition of $74.25 \%$, at concentration $4 \%, 6 \%, 8 \%$, and $10 \%$ had a strong antifungal value with growth inhibition of $82.97 \%$; $88.90 \%$; $89.49 \%$ and $91.67 \%$. Extracts of kemangi leaf had strong antifungal values (at concentration $2 \%$ and $4 \%$ ) with growth inhibition of $66.63 \%$ and $71.72 \%$, while at concentration $6 \%, 8 \%$, and $10 \%$ had a strong antifungal value with inhibition of fungal growth by $81.05 \% ; 83.02 \%$; and $100 \%$. The bioactive compounds found in kemangi leaf extracts were saponins, flavonoids, and linalool which are toxic and kill fungi. Kirinyuh leaf extract has an active alkaloid compound that is toxic and inhibits the formation of fungal cell walls. The optimal concentration of kemangi extract to inhibit the growth of Schizophyllum commune was $6 \%$ and from kirinyuh extract was $4 \%$.
\end{abstract}

Keywords: antifungi; Chromolaena odorata; Ocimum basilicum;

Schizophyllum commune;

\section{Pendahuluan}

Sejak pengusahaan kayu dimulai pada tahun 1970, kegiatan penebangan kayu kelas awet tinggi (I dan II) banyak dilakukan. Saat ini ketersediaan kayu awet tinggi untuk digunakan dalam bidang konstruksi dan penggunaan umum lainnya semakin terbatas dan harga kayu menjadi mahal. Hal ini membuat masyarakat beralih menggunakan kayu dengan kelas awet lebih rendah, yaitu kelas awet III - V. Kayu yang memiliki kelas awet rendah sering ditemukan diserang oleh jamur pelapuk kayu. Dampak dari serangan jamur menyebabkan penurunan sifat mekanik, menghancurkan penyusun dinding sel kayu dan kekuatan kayu. Jamur pelapuk kayu
Schizophyllum commune Fries merupakan jamur yang menyebabkan kerugian ekonomi tinggi. Selain menyerang kayu, jamur ini menyerang rotan, bambu, buah, dan biji-bijian.

Jamur $S$. commune dapat ditemukan di seluruh lokasi di Indonesia (Arif et al. 2012). Jamur ini menyerang berbagai hasil hutan dan produk turunan kayu serta dapat ditemukan secara alami di seluruh wilayah Indonesia. $S$. commune digunakan sebagai standar untuk pengujian ketahanan alami kayu, karena menyebabkan penurunan bobot kayu hingga lebih dari 30\% (Herliyana et al. 2011).

Upaya untuk mengendalikan jamur pelapuk kayu serta untuk memperpanjang umur pakai kayu dapat dilakukan dengan pengawetan 
kayu yaitu dengan menggunakan fungisida. Namun penggunaan fungisida dapat menimbul kan berbagai dampak negatif bagi manusia dan lingkungan serta harganya semakin mahal. Saat ini diteliti dan dikembangkan penggunaan fungisida nabati yang berasal dari bahan alam, baik tumbuhan dan hewan, dengan kriteria bahan tersebut tersedia dalam jumlah melimpah dan mudah ditemukan. Keunggulan fungisida dari bahan alam adalah senyawa bioaktif tidak menimbulkan efek samping, proses ekstraksi bahan alam saat ini lebih modern, mudah dalam pengaplikasian, dan tidak menimbulkan dampak negatif.

Salah satu syarat tumbuhan untuk menjadi fungisida nabati adalah memiliki kandungan senyawa kimia dan tersedia dalam jumlah banyak sehingga dapat diproduksi dalam jumlah massal. Tumbuhan kirinyuh dan kemangi memiliki potensi sebagai bahan fungisida nabati. Kirinyuh (Chromolaena odorata L) merupakan tumbuhan gulma famili Asteraceae yang mudah tumbuh pada berbagai sistem lahan dan bersifat sangat invasive (Luwum 2002). Tumbuhan kirinyuh dapat ditemukan di tepi jalan, kebun, pekarangan, sungai, dan sawah. Tumbuhan ini sering dinilai masyarakat sebagai gulma pengganggu dan pemanfaatannya masih kurang. Padahal kirinyuh memiliki kandungan senyawa bioaktif yang dapat menjadi fungisida seperti saponin, tannin, alkaloid, steroid dan flavonoid (Ngozi et al. 2009) yang diketahui berperan efektif untuk menekan pertumbuhan jamur pada kayu.

Hasil penelitian Diba et al (2020) menyatakan ekstraksi kirinyuh dengan metode maserasi menggunakan pelarut etanol $96 \%$ dapat menghasilkan senyawa bioaktif yang berfungsi menjadi antijamur dan antirayap. Hasil uji fitokimia ekstrak kirinyuh dengan pelarut yang sama menunjukkan hasil mengandung senyawa alkaloid, saponin, flavonoid, tanin dan fenolik (Frastika et al. 2017).

Kemangi (Ocimum basilicum L) dikenal sebagai gulma yang mudah ditemukan di tepi jalan dan tumbuh secara liar. Tanaman kemangi tumbuh dengan baik pada tanah terbuka atau agak teduh serta tidak tahan terhadap kekeringan Kemangi sering dimanfaatkan sebagai bahan pangan lalapan, termasuk tanaman hemafrodit dari famili Lamiaceae yang tersebar secara luas di Indonesia (Safwan et al. 2016).
Daun kemangi memiliki potensi untuk dijadikan sebagai bahan pengawet karena daun kemangi mengandung minyak atsiri (methyl chavicol dan linalool), flavonoid dan saponin serta yang bersifat toksik untuk pengujian terhadap jamur. Daun kemangi memiliki potensi sebagai antifungi karena senyawa bioaktif yang dimiliki termasuk senyawa toksik yang dapat menghambat pertumbuhan jamur S.commune (Dharmagadda et al. 2005). Penelitian yang mengeksplorasi potensi kemangi dan kirinyuh sebagai antifungi terhadap jamur $S$. commune serta konsentrasi yang optimal dalam menghambat serangan jamur S. commune.

\section{Bahan dan Metode}

\section{Lokasi dan Waktu Penelitian}

Penelitian dilakukan pada bulan Juni Agustus 2021, dari persiapan dan pembuatan serbuk kemangi dan kirinyuh, ekstraksi, pengujian antifungi dan pengolahan data. Pembuatan serbuk kemangi dan kirinyuh dilaksanakan di Laboratorium Wood Workshop Fakultas Kehutanan Universitas Tanjungpura dan proses ekstraksi serta pengujian antifungi dilaksanakan di Laboratorium Teknologi Kayu Fakultas Kehutanan Universitas Tanjungpura.. Alat-alat yang digunakan dalam penelitian ialah hammer mill, saringan 40 dan 60 mesh, waterbath,timbangan analitik, vortex, shaker, kertas saring, erlenmeyer, gelas ukur, beaker glass, botol reagent, corong, rotary evaporator, autoclave, jarum ose, petri dish, caliper digital, , hotplate, botol vial, aluminium foil, plastic wrap, bunsen, saringan teh, cawan porselen, mangkok, oven, dan kertas label. Bahan yang digunakan adalah isolat jamur $S$. commune, daun kirinyuh (C.odorata), daun kemangi (O. basilicum), etanol 96\%, spiritus, potatoes dextrose agar, amoxicillin $500 \mathrm{mg}$, dan aquades.

\section{Metode Penelitian}

\section{Persiapan bahan}

Daun kirinyuh dan daun kemangi yang sudah kering dijadikan serbuk dengan alat hammer mill kemudian diayak menggunakan saringan 40 mesh dan 60 mesh. Serbuk yang digunakan adalah serbuk daun kirinyuh dan daun kemangi yang lolos dari saringan 40 mesh dan tertahan 60 mesh. Kadar air serbuk dihitung 
dengan menimbang 2 gram serbuk, masingmasing untuk serbuk daun kirinyuh dan daun kemangi, kemudian dimasukkan ke dalam oven selama 24 jam. Setelah itu dikeluarkan dari oven dan ditimbang. Perlakuan diulang sampai mencapai berat konstan.

Rendemen ekstrak daun kirinyuh dan kemangi dihitung dengan melarutkan 1 gram serbuk daun kemangi dan daun kirinyuh dengan pelarut etanol dengan perbandingan $1: 3 \mathrm{~b} / \mathrm{v}$. Larutan dimaserasi dan dishaker selama $1 \times 24$ jam. Kemudian disaring dan filtrate dimasukkan dalam cawan porselen yang sudah ditimbang berat awalnya. Cawan porselen dan dipanaskan di waterbath. Residu kembali dimaserasi sampai diperoleh filtrat yang jernih.

\section{Proses ekstraksi daun kirinyuh}

Proses ekstraksi daun kirinyuh mengacu kepada Nurhalimah et al. (2014) dengan metode maserasi. Serbuk daun kirinyuh sebanyak 200 gram dilarutkan dalam etanol $96 \%$ dengan perbandingan serbuk dan pelarut 1:3 b/v. Larutan dishaker selama 48 jam, selanjutnya larutan disaring. Hasil saringan diuapkan dengan rotary evaporator kecepatan $50 \mathrm{rpm}$ dan suhu $40^{\circ} \mathrm{C}$. Selanjutnya ekstrak diuapkan pada waterbath sehingga diperoleh ekstrak murni (Rabani et al. 2017).

\section{Proses ekstraksi daun kemangi}

Proses ekstraksi daun kemangi mengacu kepada Kumalasari dan Andriana (2020). Sebanyak 200 g serbuk daun kemangi dimaserasi dengan pelarut etanol $96 \%$ dengan perbandingan 1:4 (b/v). Selanjutnya 200 gr serbuk dan $800 \mathrm{ml}$ etanol dimaserasi selama \pm 48 jam dengan shaker, kemudian disaring menggunakan kertas saring dan dilakukan secara berulang sampai hasil saringan jernih. Ekstrak cair hasil saringan di rotary evaporator untuk mendapatkan ekstrak pekat, kemudian ekstrak pekat di waterbath selama \pm 24 jam untuk menghilangkan sisa-sisa pelarut yang masih terdapat di dalam ekstrak, hingga ekstrak yang didapat berbentuk seperti butiran kristal atau jelly).

\section{Penghitungan rendemen ekstrak}

Perhitungan rendemen ekstrak daun kemangi dan daun kirinyuh berdasarkan Sunanto (2003) dengan rumus sebagai berikut:

$$
\text { Rendemen }(\mathrm{R})=\frac{A}{B} \times 100 \%
$$

Keterangan:

$\mathrm{A}=$ Berat ekstrak daun kirinyuh/daun kemangi dari hasil ekstraksi $(\mathrm{g})$

$\mathrm{B}=$ Berat serbuk daun kirinyuh/daun kemangi sebelum diekstrak (g)

\section{Pengujian Aktivitas Antifungi}

Pengujian aktivitas antifungi dilakukan menggunakan metode yang mengacu pada Khan dan Zhihui (2010) yaitu metode penghambatan pertumbuhan secara radial miselium yang telah dimodifikasi. Media PDA dicampur dengan ekstrak daun kirinyuh dan daun kemangi sesuai dengan konsentrasi perlakuan. Selanjutnya sebanyak $10 \mathrm{ml}$ larutan dimasukkan ke dalam cawan petri steril. Konsentrasi ekstrak daun kirinyuh dan daun kemangi yang diuji masingmasing ialah $0 \%, 2 \%, 4 \%, 6 \%, 8 \%$ dan $10 \%$. Kemudian isolat jamur $S$. commune dengan diameter $5 \mathrm{~mm}$ diambil menggunakan jarum ose dan diletakkan di bagian tengah cawan petri. Media uji disimpan selama 7 hari di ruangan inkubasi pada suhu ruang. Pengukuran penghambatan pertumbuhan jamur dilakukan dengan mengukur diameter miselium jamur pada hari ke tujuh setelah diinokulasi. Selanjutnya dihitung nilai anti fungal activity (AFA) menurut Mori et al. (1997) dengan rumus sebagai berikut:

$$
\mathrm{AFA}=\frac{G C-G T}{G C-A} \times 100 \%
$$

Keterangan:

$$
\begin{aligned}
\mathrm{AFA}= & \text { Aktivitas antifungi } \\
\mathrm{GC}= & \text { Pertumbuhan miselium jamur } \\
& \text { S. } \text { commune } \text { kontrol }(\mathrm{mm}) \\
\mathrm{GT}= & \text { Pertumbuhan miselium jamur } \\
& \begin{array}{l}
\text { S. } \text { commune dalam medium yang } \\
\text { dicampur ekstrak }(\mathrm{mm})
\end{array} \\
\mathrm{A}= & \text { Ukuran miselium awal jamur } \\
& \text { S. commune inkubasi }(\mathrm{mm})
\end{aligned}
$$

\section{Hasil dan Pembahasan}

\section{Rendemen Ekstrak Daun Kirinyuh \\ (Chromolaena odorata)}

Kadar air serbuk daun kirinyuh yang digunakan dalam proses ekstraksi sebesar 4,92\%. Hasil proses ekstraksi diperoleh ekstrak daun kirinyuh sebanyak 0,32 gram dengan rendemen 
sebesar 31,86\%. Nilai kadar rendemen yang dihasilkan dalam penelitian ini relatif lebih tinggi dibandingkan dengan hasil penelitian oleh Eriadi et al. (2016) sebesar 6,07\%, Jhanatra et al. (2018) sebesar $16,08 \%$ dan Nurhalimah et al. (2014) dengan nilai rendemen sebesar $17,89 \%$.

\section{Rendemen Ekstrak Daun Kemangi (Ocimum basilicum)}

Hasil ektraksi daun kemangi diperoleh kadar ekstraktif sebesar $29,38 \%$. Senyawa zat ekstraktif terbentuk dari senyawa ekstraseluler. Zat ekstraktif memiliki 3 sub golongan yaitu senyawa terpena, terpenoid dan alifatik (lemak dan lilin). Senyawa yang terdapat pada daun kemangi larut etanol 96\% (Arif et al. 2012).

Pelarut etanol merupakan pelarut organik dan dapat menarik senyawa yang bersifat organik misalnya dari golongan alifatik (lemak dan lilin), terpen dan terpenoid. Pemilihan jenis pelarut pada proses ekstraksi merupakan salah satu faktor yang menentukan keberhasilan proses ekstraksi serta banyaknya senyawa bioaktif yang diperoleh. Penggunaan pelarut etanol $96 \%$ pada penelitian ini menghasilkan hasil ekstraksi daun kemangi berwarna hijau pekat. Sejalan dengan hasil penelitian yang diperoleh, Indrawasih (2008) menyatakan dalam proses ekstraksi pemilihan jenis pelarut yang digunakan adalah variabel penting untuk menghasilkan jumlah ekstrak yang optimal.

Metode maserasi merupakan metode ekstrasi senyawa bioaktif yang paling umum digunakan karena menggunakan alat yang sederhana dan mudah dikerjakan. Namun, dalam skala industri teknik maserasi menjadi kurang efisien, karena membutuhkan waktu cukup lama. Selain itu pada proses maserasi hanya dilakukan perendaman sehingga padatan mendapatkan serapan osmosis pelarut secara statis (Pratiwi, 2010). Hasil penelitian yang telah dilakukan mendapatkan persentase kadar ekstraktif daun kemangi sebesar 29,38\%, dan hal ini sudah tergolong tinggi. Menurut Lestari dan Pari (1990), suatu bahan alam, baik tumbuhan atau hewan, tergolong memiliki kadar ekstrak tinggi jika nilai dari kadar ekstraktif yang diperoleh dari hasil akhir proses ekstraksi lebih besar dari 4\%, kemudian termasuk kadar ekstrak kelas sedang dengan kadar ekstraktif 2\% - 4\% dan termasuk kadar ekstrak kelas rendah dengan nilai kadar ekstraktif $<2 \%$.

\section{Aktivitas antifungi daun kirinyuh}

Hasil penelitian menunjukkan pertumbuhan $S$. commune pada media yang diberikan ekstrak daun kirinyuh memiliki nilai rerata aktivitas antifungi (AFA) sebesar 73,88\% - 91,90\%. Berdasarkan taraf tingkat konsentrasi, nilai rerata AFA pada perlakuan yang diberi ekstrak daun kirinyuh tergolong pada kategori kuat dan sangat kuat. Nilai rerata AFA hasil pengujian ekstrak daun kirinyuh berdasarkan taraf konsentrasi ekstrak daun kirinyuh disajikan pada Tabel 1.

Tabel 1. Rerata aktivitas antifungi (AFA) ekstrak daun kirinyuh (Chromolaena odorata) pada jamur Schizophyllum commune

\begin{tabular}{ccc}
\hline $\begin{array}{c}\text { Konsentrasi } \\
(\%)\end{array}$ & $\begin{array}{c}\text { Rerata } \\
\text { AFA }(\%)\end{array}$ & Tingkat Aktivitas \\
\hline 0 & 0 & Tidak Aktif \\
2 & 73,88 & Kuat (+++) \\
4 & 81,77 & Sangat kuat (++++) \\
6 & 88,19 & Sangat kuat (++++) \\
8 & 90,02 & Sangat kuat (++++) \\
10 & 91,90 & Sangat kuat (++++) \\
\hline
\end{tabular}

Tabel 1 menunjukkan terdapat 3 jenis tingkat aktivitas pada hasil penelitian ini, yaitu tingkat aktivitas tidak aktif pada perlakuan kontrol, kuat $(+++)$, dan sangat kuat $(++++)$. Tingkat aktivitas tidak aktif terdapat pada konsentrasi $0 \%$ yaitu pada sampel kontrol dengan nilai rerata $\mathrm{AFA}=0$. Tingkat aktivitas termasuk katagori kuat karena nilai rerata AFA di atas 50\% dan di bawah $75 \%$ yaitu terdapat pada ekstrak daun kirinyuh dengan konsentrasi $2 \%$ dengan nilai rerata AFA sebesar 73,88\%. Konsentrasi ekstrak daun kirinyuh 4\%, 6\%, 8\% dan $10 \%$ memiliki tingkat aktivitas antifungi yang termasuk kategori sangat kuat, masingmasing dengan nilai 81,77\%; 88,19\%; 90,02\% dan 91,90\%. Empat konsentrasi ini dapat menghambat pertumbuhan $S$. commune dengan sangat baik dan digolongkan sebagai tingkat aktivitas tinggi karena nilai rerata AFA sudah lebih dari $75 \%$.

Hasil penelitian menunjukkan semakin tinggi konsentrasi ekstrak daun kirinyuh yang digunakan menghasilkan semakin besar tingkat 
penghambatan pertumbuhan jamur S. commune. Hal ini sejalan dengan penelitian Sulistyawati dan Mulyati (2009) yang menyatakan semakin tinggi konsentrasi ekstrak bahan alam yang digunakan dalam pengujian cenderung meng hasilkan penghambatan pertumbuhan jamur yang semakin besar, yang berarti efektifitas ekstrak lebih baik. Konsentrasi suatu bahan alam yang akan digunakan sebagai antifungi merupakan salah satu faktor keberhasilan untuk menghambat pertumbuhan mikroorganisme yang diuji.

Hasil dari pengujian Anti-Fungal Activity (AFA) yang telah dilakukan menunjukkan bahwa konsentrasi ekstrak kirinyuh sebesar $10 \%$ merupakan konsentrasi yang menghasilkan penghambatan pertumbuhan jamur $S$. commune tertinggi. Hal ini dibuktikan dari nilai uji AFAnya yang memiliki nilai rerata tertinggi dibanding konsentrasi lainnya yaitu sebesar $91,90 \%$ yang dikategorikan sebagai tingkat aktivitas penghambat jamur sangat kuat.

Antifungi memiliki dua pengertian yaitu fungistatik dan fungisidal. Fungistatik ialah senyawa yang dapat menghambat pertumbuhan jamur tanpa mematikannya, sedangkan fungisidal merupakan senyawa yang mampu hingga mematikan jamur (Ohkubo dan Shibata 1997). Suatu komponen senyawa bioaktif dinyatakan memiliki sifat fungisidal ataupun fungistatik tergantung pada sifat dari komponen bioaktif senyawa, konsentrasi yang digunakan serta media pengujian.

Hasil penelitian ini menunjukkan bahwa kelima konsentrasi $(2 \%, 4 \%, 6 \%, 8 \%$ dan 10\%) memiliki sifat fungistatik yaitu dapat menghambat pertumbuhan $S$. commune tapi tanpa mematikannya pada pengamatan selama 7 hari. Ekstrak kirinyuh dinyatakan bersifat fungistatik karena mempunyai komponen senyawa bioaktif dengan dampak penghambatan pertumbuhan miselium jamur yang dipengaruhi oleh faktor waktu. Senyawa antifungi dengan sifat fungistatik memiliki sifat daya hambat pada suatu kerja enzim yang menyebabkan metabolis me sel jamur terganggu, hingga terhambatnya proses pemanjangan miselia (hifa) jamur. Pertumbuhan sel jamur dengan terhambatnya proses pemanjangan miselia (hifa), maka pengembangan dan fragmentasi hifa jamur akan terganggu sehingga jamur tidak bisa berkembang biak. Miselia (hifa) yang tidak dapat berfragmentasi disebabkan oleh jaringan hifa selnya rusak dan menyebabkan sel jamur pada saat yang sama menjadi rentan dan peka pada perubahan lingkungan, mengakibatkan sel jamur mengalami kematian. Rahman dan Rahman (2010) menyatakan senyawa yang memiliki sifat fungistatik misalnya senyawa fenol, termasuk pula senyawa flavonoid yang mengandung gugus fenol dan merupakan senyawa terbanyak yang ditemukan dalam ekstrak daun kirinyuh (Gultom et al. 2020) dapat menghancurkan protein, dan menyebabkan rusaknya struktur tersier protein yang menghilangkan sifat-sifat asli dari protein. Denaturasi protein dinding jamur S. commune akan menyebabkan dinding sel menjadi rapuh sehingga mudah ditembus oleh senyawa bioaktif bersifat fungistatik yang berasal dari ekstrak kirinyuh. Jika protein yang terdenaturasi oleh senyawa bioaktif dari ekstrak kirinyuh adalah protein pembentuk enzim maka mengakibatkan terganggunya metabolism sel jamur dan proses penyerapan nutrisi.

Ekstrak daun kirinyuh memiliki sifat daya hambat yang tinggi tetapi tanpa mematikan jamur S. commune pada hari ketujuh. Oleh karena itu, metode pengaplikasian antifungi dari ekstrak ini pada kayu perlu diperhatikan. Jamur $S$. commune yang diamati tidak mati yang berarti sporanya masih dapat berkembang jika perlakuan pada kayu tidak benar. Oleh sebab itu pengaplikasian ekstrak daun kirinyuh pada kayu tidak disarankan menggunakan cara spraying, terutama spraying dengan kekuatan tinggi karena terdapat kemungkinan spora jamur akan menyebar ke daerah sekitar dan tumbuh di area lainnya. Penggunaan ekstrak daun kirinyuh dengan konsentrasi perbandingan yang sama dengan penelitian ini disarankan dengan cara perendaman, atau dioles dengan menggunakan kuas/kain.

\section{Aktivitas antifungi daun kemangi}

Hasil penelitian menunjukkan ekstrak daun kemangi dapat menghambat pertumbuhan miselium jamur S.commune. Pertumbuhan jamur S. commune masih terjadi pada konsentrasi $2 \%$ dan konsentrasi $4 \%$ pada hari kedua setelah inokulasi, sedangkan pada konsentrasi $6 \%$ dan konsentrasi $8 \%$ pertumbuhan jamur baru muncul pada hari ke-4. Pertumbuhan jamur S.commune tidak terjadi pada konsentrasi ekstrak daun kemangi sebesar 10\%. Semakin tinggi 
konsentrasi ekstrak menunjukkan semakin besar penghambatan pertumbuhan jamur.

Hasil penelitian menunjukkan adanya pengaruh perbedaan pertumbuhan jamur S.commune pada tingkat konsentrasi ekstrak daun kemangi yang digunakan dalam penelitian. Pertumbuhan jamur S.commune pada media yang diberikan ekstrak daun kemangi lebih kecil dibandingkan dengan pertumbuhan jamur S.commune kontrol.

Hasil pengujian selama tujuh hari menunjukkan perbedaan nilai rerata diameter pertumbuhan miselium jamur S.commune. Perlakuan kontrol menghasilkan miselium jamur $S$. commune yang memenuhi cawan petri dengan diameter pertumbuhan $90,00 \mathrm{~mm}$, sementara pada konsentrasi $2 \%$ sebesar $33,37 \mathrm{~mm}$, dan semakin besar konsentrasi, nilai pertumbuhan diameter jamur semakin rendah. Konsentrasi $4 \%$ sebesar 29,04 mm, konsentrasi 6\% sebesar 21,10 $\mathrm{mm}$, konsentrasi $8 \%$ sebesar $14,43 \mathrm{~mm}$, dan pada konsentrasi $10 \%$ tidak ada pertumbuhan jamur S.commune. Hal ini menunjukkan perbedaan pertumbuhan miselium jamur $S$. commune pada beberapa taraf konsentrasi karena adanya daya hambat dari ekstrak daun kemangi. Nilai rerata diameter pertumbuhan jamur S.commune dengan konsentrasi uji ekstrak daun kemangi setelah masa pengujian selama 7 hari disajikan pada Gambar 1.

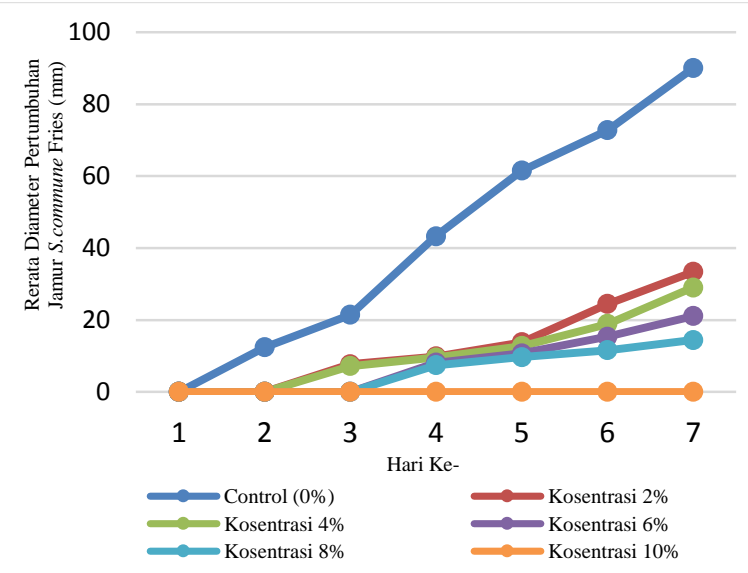

Gambar 1. Nilai rerata diameter pertumbuhan miselium jamur Schizophyllum commune berdasarkan konsentrasi ekstrak daun kemangi (Ocimum basilicum)
Menurut Kardinan (2005) esktrak daun kemangi memiliki senyawa eugenol yang berperan menghambat pertumbuhan jamur. Semakin tinggi konsentrasi ekstrak daun kemangi yang diberikan pada media pertumbuhan jamur menunjukkan penghambatan pertumbuhan jamur $S$. commune yang semakin besar. Pandey et al. (2014) menyatakan senyawa aktif pada tanaman kemangi adalah eugenol dengan persentase $6,6 \%$ memiliki sifat menghambat pertumbuhan jamur. Hasil penelitian Islamy dan Asngad (2018) menunjukkan semakin tinggi konsentrasi ekstrak daun kemangi yang digunakan menyebabkan semakin tinggi kematian lalat buah. Hal ini menunjukkan ekstrak daun kemangi memiliki potensi sebagai antijamur dan anti serangga (fungisida dan insektisida). Pertumbuhan diameter jamur S.commune hari ketujuh disajikan pada Gambar 2.

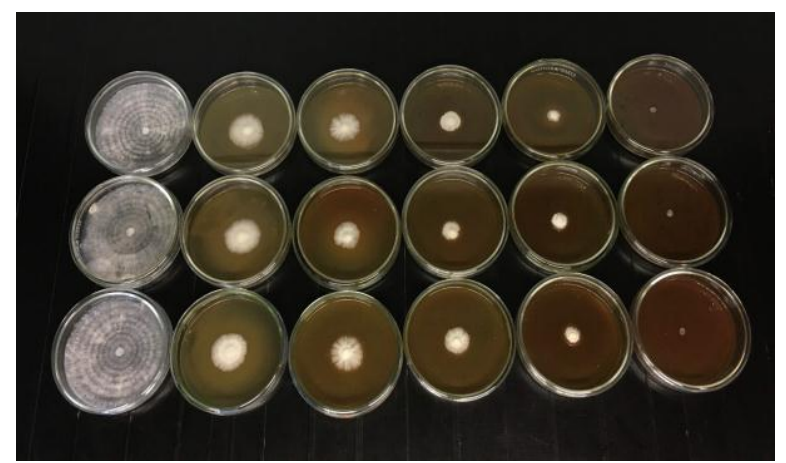

Gambar 2. Pertumbuhan diameter jamur Schizophyllum commune pada hari ke-7 pada media dengan berbagai tingkat konsentrasi ekstrak daun kemangi (Ocimum basilicum)

Perhitungan rerata nilai aktivitas antifungi (AFA) dilakukan saat pertumbuhan miselium jamur $S$. commune pada media kontrol telah memenuhi cawan petri, yaitu pada hari ke-7 masa inkubasi. Hasil penelitian menunjukkan bahwa rerata nilai aktivitas antifungi (AFA) ekstrak daun kemangi (O.basilicum) terhadap jamur S.commune adalah $66,63 \%$ sampai $100,00 \%$.

Nilai rerata aktivitas antifungi (AFA) ekstrak daun kemangi terhadap jamur S.commune yang disajikan pada Tabel 2 menunjukkan variasi nilai AFA pada masingmasing perlakuan terkecuali kontrol. Pemberian perlakuan ekstrak daun kemangi pada media mempengaruhi pertumbuhan jamur S.commune. 
Nilai rerata AFA ekstrak daun kemangi (O.basilicum) terhadap jamur S.commune berdasarkan taraf konsentrasi disajikan pada Tabel 2.

Tabel 2. Rerata aktivitas anti jamur ekstrak daun kemangi (O.basilicum) terhadap pertumbuhan jamur Schizophyllum commune

\begin{tabular}{|c|c|c|}
\hline $\begin{array}{c}\text { Konsentrasi } \\
\%\end{array}$ & Rerata AFA \% & $\begin{array}{c}\text { Tingkat } \\
\text { Aktivitas }\end{array}$ \\
\hline $0 \%$ & 0,00 & Tidak Aktif \\
\hline $2 \%$ & 66,63 & Kuat $(+++)$ \\
\hline $4 \%$ & 71,72 & Kuat $(+++)$ \\
\hline $6 \%$ & 81,05 & $\begin{array}{l}\text { Sangat Kuat } \\
(++++)\end{array}$ \\
\hline $8 \%$ & 83,02 & $\begin{array}{l}\text { Sangat Kuat } \\
(++++)\end{array}$ \\
\hline $10 \%$ & 100,00 & $\begin{array}{l}\text { Sangat Kuat } \\
(++++)\end{array}$ \\
\hline
\end{tabular}

Pemberian ekstrak daun kemangi pada media PDA terbukti menghambat pertumbuhan miselium jamur S.commune. Pertumbuhan miselium jamur $S$. commune pada media dengan ekstrak daun kemangi relatif lebih kecil dibandingkan dengan pertumbuhan pada media kontrol. Konsentrasi 2\% dan konsentrasi 4\% menunjukkan nilai daya hambat kuat terhadap pertumbuhan jamur S.commune, sedangkan pada konsentrasi $6 \%, 8 \%$, dan $10 \%$ menunjukkan nilai daya hambat sangat kuat. Daya hambat pertumbuhan jamur S.commune pada media dengan ekstrak daun kemangi disebabkan adanya senyawa bioaktif yang bersifat antifungi dari ekstrak daun kemangi. Noviansari et al. (2013) menyatakan kandungan bioaktif dari daun kemangi meliputi minyak atsiri, antrakuinon, flavonoid, saponin, karbohidrat, tanin, alkaloid, fenolik, pati, terpenoid, fitosterol dan lignin. Ridhwan dan Isharyanto (2016) menyatakan daun kemangi berpotensi sebagai pestisida nabati.

Ekstrak daun kemangi memiliki senyawa bioaktif yang berfungsi sebagai antijamur. Menurut penelitian Sulianti (2008) ekstrak daun kemangi mengandung komponen utama seperti linalool, Z-sitral, geranial, dan metil eugenol. Menurut Silalahi (2018) ekstrak daun kemangi memiliki senyawa yang berasal dari derivat monotherpene (geraniol, camphor, 1,8-cineole, linalool, limonene) dan derivat phenylpropanoid (methyleugenol, chavicol, eugenol, estragole dan methyl-cinnamate). Tumbuhan kemangi memiliki aktivitas analgetik, anti-inflamasi, antimikroba, kemomodulator, antioksidan, anti ulserogenik, depresan saraf pusat, stimulant jantung, hipoglikemik, larvasida, imunomodula tor, hepatoprotektif, dan hipolipidemik (Bilal et al. 2012). Ekstrak daun kemangi menunjukkan efek antibakteri, insektisida dan antijamur (Khare, 2007).

Penelitian Bihari et al. (2011) menyatakan daun kemangi mempunyai 9 komponen utama dengan nilai kadar diatas $2 \%$ yaitu asam etil heksadekanoat, asam metil heksadekanoat, linalool, Z-sitral metil eugenol, geranial, asam etil oktadekanoat, 3-metilsiklopent-2-enona, dan asam etil 9-oktadekenoat. Skrining fitokimia pada daun kemangi menghasilkan senyawa dan komponen seperti alkaloid, glikosida, karbohidrat, gums mucilage, protein, lemak, asam amino, tanin, senyawa fenolik, triterpenoid, steroid, sterol, saponin, flavonoid, resin dan flavons.

Menurut Purushothaman (2018) kemangi secara umum mengandung sekitar 20 senyawa seperti linalool, estragole, metil eugenol,8cineole, Camphor, limonene, thymol, citral. Linalool $(52,42 \%)$, metil eugenol $(18,74 \%), 1,8$ cineol $(5,61 \%)$ adalah senyawa utama kemangi. Ekstrak daun kemangi memiliki sifat anti konvulsan, anti-trombotik anti-hiperlipidemia, antiinflamasi, imunomodulator, anti oksidan, antiplatelet, anti-mikroba, insektisida, dan sitotoksisitas.

Kardinan (2005) menyatakan bahwa bagian daun memiliki kandungan minyak atsiri seperti eugenol, alfa pinene, geraniol, metil eugenol, ocimene, anetol, ecalyptole, linalool, camphor, methylchavinol, dan methylcinnamate. Hasil uji BNJ menunjukkan penghambatan pertumbuhan miselium jamur S.commune dengan ekstrak daun kemangi pada konsentrasi $2 \%$ dapat menghambat pertumbuhan miselium jamur S.commune dengan katagori tingkat penghambatan kuat dan rerata nilai AFA 66,63\%, dan pada konsentrasi 6\% dapat menghambat pertumbuhan jamur S.commune dengan tingkat penghambatan sangat kuat dan rerata nilai AFA 81,05\%.

Berdasarkan hasil penelitian yang telah dilakukan, uji aktivitas antifungi ekstrak daun kemangi terhadap penghambatan pertumbuhan jamur $S$. commune menunjukkan konsentrasi $10 \%$ merupakan konsentrasi dengan daya hambat tertinggi yaitu sebesar 100,00\%. Ekstrak daun 
kemangi cukup mampu dijadikan bahan pengawet alami. Salah satu alasannya adalah bahan baku yang cukup mudah ditemukan di pekarangan masyarakat.

\section{Kesimpulan}

Ekstrak daun kirinyuh (Chromolaena odorata) dengan konsentrasi $10 \%$ mampu menghambat pertumbuhan jamur Schizophyllum commune dengan nilai penghambatan sebesar 91,90\% dengan kategori AFA sangat kuat. Ekstrak daun kemangi (O.basilicum) dengan konsentrasi $10 \%$ mampu menghambat pertumbuhan jamur S.commune dengan dengan kategori AFA sangat kuat dan nilai penghambatan $100,00 \%$. Nilai rendeman ekstrak daun kirinyuh sebesar $31,86 \%$ dan ekstrak daun kemangi sebesar 29,38\%. Berdasarkan kategori AFA, konsentrasi yang optimal sebagai bahan pengawet kayu untuk menghambat pertumbuhan jamur Schizophyllum commune dengan katagori penghambatan sangat kuat, dari ekstrak daun kemangi sebesar $6 \%$ dan ekstrak daun kirinyuh sebesar $4 \%$.

\section{Ucapan terima kasih}

Penulis menyampaikan terima kasih kepada Fakultas Kehutanan Universitas Tanjungpura yang telah membiayai penelitian dengan Dana DIPA Tahun 2021 berdasarkan Surat Perjanjian Pelaksanaan Penelitian dengan nomor kontrak 2041/UN22.7/HM/2021 tanggal 25 Mei 2021.

\section{Referensi}

Achmadi SS. (1990). Kimia Kayu. Bogor: Departemen Pendidikan dan Kebudayaan Direkorat Jendral Pendidikan Tinggi Universitas Ilmu Hayat IPB. (https://docplayer.info/139384209-

Achmadi-s-s-kimia-kayu-direktoratjenderal-pendidikan-tinggi-departemenpendidikan-dan-kebudayaan-pau-ilmuhayat-ipb-bogor.html)

Arif AM, Natsir U, \& Fatmawaty S. (2012). Sifat Anti Rayap dari Ekstrak Ijuk Aren Arenga pinnata Merr. Jurnal Parrenial 3:15-18. (DOI:https://doi.org/10.24259/perennial.v 3i1.165)
Bihari GC, Manaswini B, Kumar PJ, \& Kumar TS. (2011). Pharmacognostical and phytochemi cal investigation of various tulsi plants available in south estern odisha. Journal of Research in Pharmaceutical and Biomedical Science 2 (2):605-610.

(https://www.yumpu.com/en/document/vi ew/11516642/pharmacognostical-andphytochemical-investigation-of-varioustulsi-)

Bilal A, Nasreen J, Ajij A, Saima NB, Shahida H, \& Syeda H. (2012). Phytochemical and pharmacological studies on Ocimum basilicum Linn. International Journal of Current Research and Review (IJCRR) 4(23):73-83. (http://ijcrr.com/article_html.php?did=15 38)

Dharmagadda VSS, Tandonb M, \& Vasudevan P. (2005). Biocidal Activity of The Essential Oils of Lantana camara, Ocimum sanctum and Tagetes patula. Journal of Scientific \& Industrial Research 64(1):53-56. (http://nopr.niscair.res.in/handle/1234567 89/5003)

Diba F, Sidik MN, \& Setyawati D. (2020). Bioaktivitas ekstrak daun dan batang kirinyuh (Eupatorium odoratum L) terhadap rayap tanah Coptotermes curviganthus Holmgren. Proseding Seminar Nasional Fakultas Kehutanan Universitas Tanjungpura, Peran Penelitian Kehutanan untuk Meningkatkan Produkti vitas Hutan dan Kesejahteraan Masyara kat. Pontianak 22 Desember 2020 UNTAN Press. ISBN 978-623-7571-32-2 hal

201-210. (https://fahutan.untan.ac.id/2021/08/prosi ding-seminar-nasional-dalam -rangkadies-natalis-ke-20-fakultas-kehutananuniversitas-tanjungpura)

Eriadi A, Arifin H, \& Nirwanto (2016). Uji toksisitas akut ekstrak etanol daun kirinyuh (Chromolaena odorata (L) R.M.King \& H.Rob) pada mencit putih jantan. Jurnal Farmasi Higea 8(2):122132.

(https://www.jurnalfarmasihigea.org/inde x.php/higea/article/view/144) 
Frastika D, Pitopang R, \& Suwastika IN. (2017). Uji efektivitas ekstrak daun kirinyuh (Chromolaena Odorata (L.) R. M. King dan H. Rob) sebagai herbisida alami terhadap perkecambahan biji kacang hijau (Vigna radiata (L.) R.Wilczek) dan biji karuilei (Mimosa invisa Mart. ex Colla). Journal of Science and Technology 6(3):225-238.

(DOI:https://doi.org/10.22487/25411969. 2017.v6.i3.9195)

Gaspertz V. (1991). Metode Perancangan Percobaan. Bandung: Armico. http://www.vincentgaspersz.com/pubs/me tode-perancangan-percobaan-untuk-ilmuilmu-pertanian-dan-ilmu-ilmu-teknikbiologi/)

Gultom ES, Sakinah M, \& Hasanah U. (2020). Eksplorasi senyawa metabolit sekunder daun kirinyuh (Chromolaena odorata) dengan gc-ms. Jurnal Biosains 6(1):23-26. (https://jurnal.unimed.ac.id/2012/index.ph p/biosains/article/view/16450)

Harborne JB. (1987). Metode Fitokimia: Penuntun Cara Modern Menganalisis Tumbuhan. Terb ke-2. Padmawinata K, Soediro W, Penerjemah; Niksolihin S, editor, Bandung: ITB. Terjemahan dari: Phytochemical Methods. (DOI:https://doi.org/10.1007/978-94-0095570-7)

Herliyana EN, Maryam LF, \& Hadi YS. (2011). Schizophyllum commune Fr. sebagai jamur uji ketahanan kayu Standar Nasional Indonesia pada empat jenis kayu rakyat: Sengon (P. falcataria), Karet $(H$. brasiliensis), Tusam ( $P$. merkusii), Mangium (A. mangium). Jurnal Silvikultur Tropika 2(3):176-180. (https://journal.ipb.ac.id/index.php/jsilvik / article/view/5383)

Indrawasih A. (2008). Optimasi Pembuatan Ekstrak Daun Daru (Eugenia uniflora L.) menggunakan metode maserasi dengan parameter kadar total senyawa fenolik dan flavonoid. Surakarta: Universitas Muhammadiyah Surakarta. (http://eprints.ums.ac.id/983/)

Islamy, F., \& Asngad, A. (2018). Pemanfaatan Tanaman Kemangi (Ocium basillum L.) dan Kulit Jeruk Nipis Sebagai Insektisida Nabati Terhadap Pengendalian Lalat Buah
Dalam Berbagai Konsentrasi dan Pelarut. Prosiding Seminar Nasional Pendidikan Biologi dan Saintek ke-3 hal: 418-424. (http://hdl.handle.net/11617/10524)

Kardinan A. (2005). Tanaman Penghasil Minyak Atsiri. Jakarta: Penerbit Agro Media Pustaka.

(https://agromedia.net/katalog/tanamanpenghasil-minyak-atsiri/)

Khan MA, \& Zhihui C. (2010). Influence of garlic root exudates on cytomorphological alteration of the hyphae of phytophthora capsici, the cause of phytophthora blight in pepper. Journal Botanical 42(6):4353-4361. (http://www.pakbs.org/pjbot/)

Khare C. (2007). Indian Medical Plannts, an Illustrated Dictionary, Springer. India. (DOI:https://doi.org/10.1007/978-0-38770638-2)

Kumalasari MLF, \& Andiarna F. (2020). Uji Fitokimia Ekstrak Etanol Daun Kemangi (Ocimum basilicum L). Journal for Health Sciences 4(1):39-44. (DOI:doi.org/10.24269/ijhs.v4i1.2279)

Lestari SB, \& Pari G. (1990). Analisis Kimia Beberapa Jenis Kayu Indonesia. Jurnal Penelitian Hasil Hutan Pusat Penelitian dan Pengembangan Hasil Hutan 7(3):96100 (http://ejournal.forda-mof.org/ejour nal-litbang/index.php/JPHH/article/view 13460)

Luwum P. (2002). Control of invasive Chromolaena odorata: an evaluation in some land use types in KwaZulu, South Africa. International Institute for GeoInformation Science and Earth Observati on.Enschede

(https://webapps.itc.utwentenl/library/ww w/papers2003/msc/nrm/luwum.pdf)

Mori M, Aoyama M, Doi S, \& Kanetoshi A, Hayashi T. (1997). Antifungal activity of bark extracts of deciduous trees. Journal Holz als roh-und Werkstoff 55(2-4):130132.

(DOI:https://doi.org/10.1007/BF02716394

Ngozi IM, Jude IC, \& Catherine IC. (2009). Chemical profile of Chomolaena odorata L. (King and Robinson) leaves. Pakistan Journal of Nutrition 8(5):523. (DOI:https://doi.org/10.3923/pjn.2009.52 1.524) 
Noviansari R, Sudarmin, \& Siadi K. (2013). Transformasi metil eugenol menjadi 3 (3,4 dimetoksi fenil) - 1- propanol dan uji aktivitasnya sebagai antibakteri. Indonesian Journal of Chemical Science 2 (2):114-118. (http://journal.unnes.ac.id /sju/index.php/ijcs)

Nurhalimah H, Novita W, \& Tri DW. (2014). Efek antidiare ekstrak daun beluntas (Pluchea indica Less) terhadap mencit jantan yang diinduksi bakteri Salmonella thypimurim. Jurnal Pangan dan Agroindustri 3(3):1083-1094. (https://jpa.ub.ac.id/index.php/jpa/article/ view/231)

Ohkubo T, \& Shibata M. (1997). The selective capsaicin antagonist capsazepine abolishes the antinociceptive action of eugenol and guaiacol. Journal of Dental Research 76(4):848-851. (DOI:https://doi.org/10.1177/0022034597 0760040501)

Pandey A, Pooja S, \& Nijendra N. (2014). Chemistry and bioactivities of essential oils of some Ocimum species: an overview. Asian Pacific Journal of Tropical Biomedicine 4(9):682-694. (https://doi.org/10.12980/APJTB.4.2014C 77)

Pratiwi E. (2010). Perbandingan Metode Maserasi, Remaserasi, Perkolasi dan Reperkolasi dalam Ekstraksi Senyawa Aktif Andrographolide dari Tanaman Sambiloto (Andrographis paniculata (Burm.F.) Nees). Bogor: Institut Pertanian Bogor.

(https://repository.ipb.ac.id/handle/12345 6789/62199)

Purushothaman, Purushothaman B, Prasanna SR, Suganthi P, Ranganathan B, Gimbun J, \& Shanmugam K. (2018). A comprehensive review on Ocimum basilicum. Journal of Natural Remedies 18(3):71-85.

(DOI:https://doi.org/10.18311/jnr/2018 /21324)

Rabani, Diba F, \& Muflihati (2017). Penghambatan pertumbuhan jamur Schizophyllum commune Fries oleh ekstrak etanol daun kratom (Mitragyna speciosa Korth). Jurnal Hutan Lestari 5(3):831-839. (https://jurnal.untan.ac.id/index.php/jmfk $\mathrm{h} /$ article/view/21714)

Rahman N, \& Rahman AKN. (2010). Uji fungistatik ekstrak daun sirih (Piper betle L.) terhadap Candida albicans. Jurnal Bioscientiae 7(2):17-24. (DOI: https://doi.org/10.20527/b.v7i2.180)

Ridhwan M, \& Isharyanto. (2016). Potensi Kemangi Sebagai Pestisida Nabati. Serambi Saintia 4(1):18-26. (http://ojs.serambimekkah.ac.id/index.php /serambi-saintia/article/view/112)

Safwan f, Sugara T, \& Rohmi MK. (2016). Pengaruh Ekstrak Daun Kemangi (Ocimum sanctum L.) Terhadap Motilitas dan Konsentrasi Spermatozoa Mencit Jantan (Mus musculus). Jurnal Ilmiah Ibnu Sina 1(2):173-181. (https://e-jurnal.stikesisfi.ac.id/index.php/JIIS/article/view/47)

Silalahi M. (2018). Minyak essensial pada kemangi (Ocimum basilicum L.). Jurnal Pro-Life 5(2):557-566

(http://ejournal.uki.ac.id/index.php/prolife /article/view/710)

Sjostrom E. (1995). Kimia Kayu: Dasar-Dasar dan Penggunaan, Edisi Kedua. Yogyakarta: Gadjah Mada University Press.

(http://lib.kemenperin.go.id/neo/detail.ph $\mathrm{p}$ ?id=225334)

Suharjo E. (2007). Budi daya jamur merang dengan media kardus. Jakarta: Agromedia pustaka. (https://agromedia.net/katalog/budi-dayajamur-merang-dengan-media-kardus/)

Sulianti BS. (2008). Studifitokimia ocimum spp: komponen kimia minyak atsiri kemangi dan ruku-ruku. Berita Biologi 9(3): 237241. (https://e-journal.biologi.lipi.go.id/in dex.php/berita_biologi/article/view/778)

Suharjo R, \& Aeny TN. (2011). Eksplorasi potensi gulma siam (Chromolaena odorata) sebagai biofungisida pengendali Phytophthora palmivora yang diisolasi dari buah kakao. Jurnal Hama dan Penyakit Tumbuhan Tropika 11(2):201209.

(DOI:https://doi.org/10.23960/j.hptt.2112 01-209)

Sulistyawati D, \& Mulyati S. (2009). Uji aktivitas antijamur infusa daun jambu mete (Anacardium occidentale L.) terhadap 
Diba, F et al. (2022). Jurnal Biologi Tropis, 22 (1): 304 - 314

DOI: http://dx.doi.org/10.29303/jbt.v22i1.3023

Candida albicans. Jurnal Biomedika 2(1):47-51.

(http://ejurnal.setiabudi.ac.id/ojs/index.ph $\mathrm{p} /$ biomedika)

Wijayanti, Budi. (2003). Penggunaan Serratia mercescens DS8 untuk Pengendalian Penyakit Busuk Batang Panili. Bogor: Institut Pertanian Bogor. Skripsi. (https://repository.ipb.ac.id/handle/12345 6789/33535) 